\title{
Effects of different drying methods on fermentation characteristics and viability of cold-adaptive yeast
}

\author{
Seong Yeol Baek, Ji-Young Mun, Soo-Hwan Yeo* \\ Department of Agro-food Resource, National Institute of Agricultural Science, RDA, Wanju 55365, Korea
}

저온 적응성 효모의 보존방법에 따른 균체의 생존율 및 발효특성

\author{
백성열 · 문지영 · 여수환* \\ 농촌진흥청 국립농업과학원 농식품자원부
}

\begin{abstract}
The quality characteristics of Yakju and survival rate of yeast were investigated by modifying the drying method for the cold adapted yeast strain Saccharomyces cerevisiae Y297 (SCY297). Viability and fermentation characteristics of the freeze-dried, air blast-dried, and liquid SCY297 cultures were compared after storing them at $25^{\circ} \mathrm{C}$. In addition, $5 \%$ skimmed milk, a-lactose, or trehalose was added as a protective agent for examining the effects of drying methods. During the 15-week storage period, the liquid and freeze-dried SCY297 cultures containing a protective agent showed a survival rate of $80 \%$. However, the air blast-dried SCY297 culture showed $80 \%$ survival rate only in the skimmed milk supplemented group. Compared to the untreated cells, the acidity and amino acidity of Yakju prepared using freeze-dried or air blast-dried cultures of SCY297 increased by 2 fold and 5.7 fold respectively, while the alcohol content decreased by 5.07\%. Compared to the untreated cells, the $\mathrm{pH}$ and amino acidity of Yakju prepared using the liquid culture of SCY297 increased by 1.5 fold and 2.5 fold respectively. Although the alcohol content decreased by $2.9 \%$, decrease rate was lower than that observed for the freeze-dried and air blast-dried yeast cultures. Therefore, the results of this study showed that using a liquid starter culture was more advantageous than using the conventional solid culture.
\end{abstract}

Key words : Saccharomyces cerevisiae, fermentation, viability, drying, starter

\section{서 론}

우리나라 전통주의 하나인 약주는 찹쌀, 멥쌀 등의 곡류 에 누룩을 첨가하여 당화와 발효가 동시에 진행되는 병행복 발효주이다. 약주는 발효 중 미생물이 생산한 효소에 의해 유기산, 휘발성 향기성분, 생리활성물질과 당분이 생겨나 독특한 맛과 향을 가진다. 최근, 탁 · 약주 제조에서 알코올 뿐만 아니라 맛과 향에 대한 관심이 높아지고 있으며, 이를 매개하는 효모의 중요성이 대두되고 있다(1).

*Corresponding author. E-mail : yeobio@korea.kr

Phone : 82-63-238-3610, Fax : 82-63-238-3843

Received 27 September 2017; Revised 8 November 2017; Accepted 9 November 2017.

Copyright (c) The Korean Society of Food Preservation. All rights reserved.
국내 대부분의 주류 제조사는 수입산 효모 종균인 Saccharomyces cerevisiae Fermivin(프랑스), S. cerevisiae $\mathrm{W}-3$ (일본), S. cerevisiae $\mathrm{EC} 1118$ (캐나다) 등 와인용 또는 제빵용 효모를 사용하고 있다. 수입 종균은 사용하기가 편 리하고 주질이 안정적으로 유지되는 장점이 있어 주류업체 에서 선호하는 실정이다. 최근 보고된 연구에 따르면 국내 에서 분리된 토착 효모가 우리 술을 만드는데 기여할 수 있음을 보고하였다 $(2,3)$. 우리나라를 대표하는 탁 - 약주가 수입산 주류보다 경쟁력과 차별성의 우위를 점하기 위해서 는 수입 효모 대신 한국산 유용 효모를 분리하여 사용할 필요가 있다(4,5). 따라서 탁 - 약주 생산을 위한 첫걸음은 가장 한국적인 효모 종균(스타터)을 개발하여 현장적용을 거친 후, 농산업체에 기술이전을 통한 국산 종균의 보급을 높이는데 있다.

발효미생물은 나름대로 균주별 고유의 특성을 가지고 
있지만 내외부 환경변화로 인해 본래의 특성을 잃어버리기 쉽다. 따라서 산업적으로 이용하기 위해서는 무엇보다도 변이가 없는 종균의 안정성이 요구된다. 이러한 종균을 개 발하기 위한 가장 중요한 요소로써 세포 생존율 유지, 장기 저장 용량 및 건조 방법 등이 있다. 미생물 고유의 특성 유지와 종균의 산업적 활용 빈도를 높이기 위해, 미생물의 동결 건조법(6), 유동층 건조(7) 및 분무 건조법(8) 등 다수 의 연구 결과들이 보고되었다. 현재 시판되는 다수의 산업 용 효모 제품은 발효액을 동결 감압시킨 후 얼음의 승화에 의해 수분을 제거하는 동결 건조법을 이용한다. 이와 같은 방법은 다른 건조 방법에 비해 물리적 구조의 복원성과 화학적 안정성의 특징을 가지고 있지만(9) 건조 시간이 길 고 종균의 재생율 저하뿐만 아니라 에너지와 비용이 많이 투입되기 때문에 제품화를 위한 기술로는 문제점을 가지고 있다(10). 유동층 건조 및 분무 건조의 경우는 건조 중 고온 으로 인한 스타터 배양균의 생존력이 낮기 때문에 적합하지 않다. 하지만, 송풍 건조는 비용을 낮추어 세포 손상을 적게 유도하고 다른 건조 방법(11)과 비교하여도 초기 수분 조절 이 용이하고 복원 결과, 재생률이 높아 국내외 종균업체에 서 널리 사용하고 있는 대표적인 방법 중 하나이다. 또한 액상 종균은 저장 능력에 대한 한계, 특정 포장과 취급에 대한 단점을 가지지만, 건조과정을 거치치 않아 비용을 낮 추는 점과 발효기간 단축으로 다양한 미생물에 적용 가능한 것이 장점으로 알려져 있다(12).

본 연구에서는 저온 적응성 효모의 액체 종균제조 가능 성을 높이기 위하여 기존에 알려진 동결건조와 송풍건조 방법으로 제형화하여 액체 종균과 비교하였으며 이들 효모 의 장기 저장에 따른 생존율과 발효 특성 등을 조사하였다.

\section{재료 및 방법}

\section{효모 균주 및 재료}

본 실험에서 사용한 균주는 선행 연구에서 선발된 효모 로 한국농업미생물유전자원센터(KACC)에 등록한 것으로 $15^{\circ} \mathrm{C}$ 에서 생육정도가 높은 Saccharomyces cerevisiae Y297 (KACC93244P, SCY297)를 사용하였다(13). 실험에 사용된 효모는 yeast extract $1 \%$, peptone $2 \%$, dextrose $2 \%$ (YPD, $\mathrm{BD}$, Franklin Lakes, NJ, USA) 액체배지에 배양 후, $20 \%$ glycerol을 첨가하여 $-80^{\circ} \mathrm{C}$ 에서 보관하여 사용하였다. 약주 제조에 사용한 백국은 (주조은곡식(경기도 화성시)에서 구 입하였고, 멥쌀은 2014년 9월 경기도 철원에서 재배된 오대 미를 사용하였다. 정제효소는 (주충무발효에서 구입하여 약 주제조에 사용하였다.

\section{쌀 당화액 제조}

쌀 당화액은 멥쌀을 세척하고 약 2시간 동안 물에 침지한 후, 1 시간 물 빼기를 하였다. 멥쌀을 1 시간 동안 증자한 후에 냉각하였다. 멥쌀 $6 \mathrm{~kg}$ 을 기준으로 $5 \mathrm{~L}$ 의 플라스틱 통에 각각 고두밥 $3 \mathrm{~kg}$ 과 입국(Koji, Joeungoksik Co., Ltd, Hwaseong, Korea) $540 \mathrm{~g}$ 넣은 후, 물 $4.5 \mathrm{~L}$ 첨가하여 잘 혼합하여, $40^{\circ} \mathrm{C}$ 에서 3 일간 발효한 후, 쌀 당화액으로 사용하 였다(Fig. 1). 쌀 당화액은 고압증기멸균기를 이용하여 12 $1^{\circ} \mathrm{C}$ 에서 15 분간 멸균하였다.

\section{합성배지 및 쌀 당화액에서 효모의 생육도 조사}

시험구로써 합성배지인 $\mathrm{YPD}(\mathrm{Con})$, 합성배지에 $2 \%$ 효모 추출물(YPD+YE), 합성배지에 $2 \%$ 펩톤(YPD+P), 합성배지 에 $2 \%$ 덱스트로오스( $\mathrm{YPD}+\mathrm{D})$, 쌀 당화액(SM), 쌀 당화액에 $2 \%$ 효모 추출물과 $2 \%$ 펩톤을 각각 첨가한 액 $(\mathrm{SM}+\mathrm{YE}+\mathrm{P})$ $10 \mathrm{~mL}$ 에 전배양액 $\mathrm{SCY} 297$ 효모를 $0.1 \%$ 접종하여 $30^{\circ} \mathrm{C}$ 에 서 24시간 진탕배양한 후, 생균수를 측정하였다.

\section{효모 제형화 방법}

쌀 당화액 배지 $(750 \mathrm{~mL})$ 에 SCY 297의 접종량은 전배양 액 $30 \mathrm{~mL}$ 으로 접종하였으며, 진탕배양기(Wisd RWIS-20R, Daihan Scientific Co., Ltd., Wonju, Korea)로 $25^{\circ} \mathrm{C}$ 에서 48 시 간 동안 $120 \mathrm{rpm}$ 으로 배양하였다. 배양 후, $12,000 \mathrm{rpm}$, $7 \mathrm{~min}$ 조건에서 원심분리(VS-24SMTi, VISION SCIENTIFIC Co., Ltd., Hwaseong, Korea)를 하였다. 액체 제형은 효모 배양 농축액량을 $300 \mathrm{~mL}$ 로 하였으며, 각각의 부형제 $(\mathrm{a}$ -lactose, trehalose, skim milk) $5 \%$ 를 혼합 한 후, falcon tube에 $40 \mathrm{~mL}$ 씩 담아 $25^{\circ} \mathrm{C}$ 에 저장하였다.

동결건조 제형은 각각의 액체 제형(무처리, $5 \%$ 알파 락 토오스, $5 \%$ 트레할로오스, $5 \%$ 스킴 밀크)을 specimen cup(SPL life Science Co., Ltd., Pocheon, Korea) 용기에 90 $\mathrm{mL}$ 씩 넣은 후, 초저온냉동고(ilShin $(\mathrm{R})$ DF8517, IIShinBioBase Co., Ltd., Yangju, Korea)에 24시간 보관하였다. 특히,

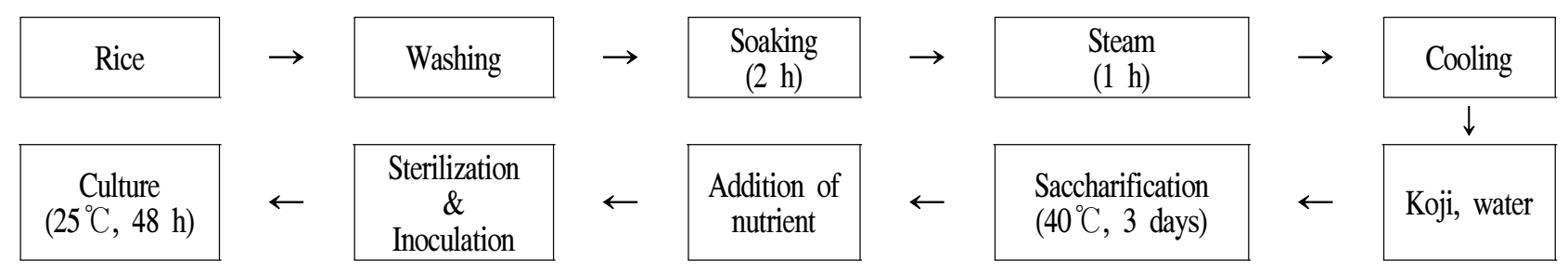

Fig. 1. Schematic processing of rice saccharified medium. 
specimen cup의 위 표면을 호일로 포장하여 공기가 통과할 수 있도록 하고 시료를 넣어 8 일 동안 동결건조 $\left(-75^{\circ} \mathrm{C}\right)$ 를 하였다. 동결건조 후, 시료는 $25^{\circ} \mathrm{C}$ 에 저장하였다.

송풍건조 제형은 각각의 액체 제형(무처리, $5 \%$ 알파 락 토오스, $5 \%$ 트레할로오스, $5 \%$ 스킴 밀크)을 specimen cup 용기에 $40 \mathrm{~mL}$ 씩 넣은 후, 용기의 위 표면을 랩핑 한 다음, 공기가 통할 수 있도록 구멍을 만들었다. 중력대류식 방법 으로 온도를 $40^{\circ} \mathrm{C}$ 에서 2 일간 건조한 후에 $25^{\circ} \mathrm{C}$ 에 저장하였 다.

\section{생존율 측정}

효모 균체의 생존율을 측정하기 위해, 건조 전 배양액 $1.0 \mathrm{~mL}$ 를 적절한 배수로 희석하여 YPD 고체배지에 100 $\mu \mathrm{L}$ 를 분주하여 도말한 후, $30^{\circ} \mathrm{C}$ 에서 48 시간 배양하여, 형성 된 콜로니를 계수하여 colony forming unit을 대수함수(log $\mathrm{CFU} / \mathrm{mL}$ )로 나타내어 초기 균수로 정하였다. 액체 및 건조 균체 또한 위와 같은 방법으로 균수를 측정하여 다음과 같은 방정식으로 각각의 생존율을 측정하였다(14).

$$
\text { 생존율 }(\%)=\frac{\text { 액체 및 건조된 균수 }\left(\mathrm{N}_{\mathrm{t}}\right)}{\text { 초기 균수 }\left(\mathrm{N}_{0}\right)} \times 100
$$

\section{약주 담금 및 발효}

멥쌀 $1 \mathrm{~kg}$ 을 씻어 2시간 동안 물에 담근 다음, 물 빼기와 증자를 각각 1 시간 한 후, 냉각하였다. $2 \mathrm{~L}$ 용기에 고두밥과 입국 $180 \mathrm{~g}$, 정제효소(Choongmoo Fermentation Co., Ltd., Ulju, Korea) $1 \mathrm{~g}$, 담금수 $1.5 \mathrm{~L}$ 를 넣은 후, 각각의 건조 효모(동결, 송풍 및 액체)를 쌀 당화액에 전배양하여 중량의 $1 \%$ 를 접종하여 $20^{\circ} \mathrm{C}$ 에서 14 일간 발효하였다. 제조된 밑술 은 원심분리 후, 분석용 시료로 사용하였다.

\section{이화학 분석}

$\mathrm{pH}$ 는 시료 $10 \mathrm{~mL}$ 를 취하여 $\mathrm{pH}$ meter(FE20, Mettler Toledo, Switzerland)로 측정하였으며, 적정산도는 시료 5 $\mathrm{mL}$ 에 $1 \%$ 페놀프탈레인 지시약을 2-3방울 떨어뜨린 후, $\mathrm{pH}$ 가 8.3이 될 때까지 $0.1 \mathrm{~N} \mathrm{NaOH}$ 용액으로 적정하여 acetic $\operatorname{acid}(\%)$ 로 환산하였다. 고형분 함량은 당도계
(ATAGO Pocket PAL-1, ATAGO Co., Tokyo, Japan)를 사용 하여 측정하였다. 아미노산도는 시료 $10 \mathrm{~mL}$ 에 $1 \%$ 페놀프 탈레인 지시약 2-3방울을 가하고 $0.1 \mathrm{~N} \mathrm{NaOH}$ 용액으로 중화한 후 중성포르말린 용액 $5 \mathrm{~mL}$ 를 넣고 $0.1 \mathrm{~N} \mathrm{NaOH}$ 용액으로 담홍색이 될 때까지 적정하여 측정하였다(15). 알코올 함량은 시료 $100 \mathrm{~mL}$ 를 취하여 증류수 $100 \mathrm{~mL}$ 를 가한 후, 가열 증류를 통하여 $80 \mathrm{~mL}$ 의 증류액을 얻었다. 이를 증류수로 $100 \mathrm{~mL}$ 정용한 다음, 비중계로 알코올 도수 (\%)와 온도를 측정하고 국세청 보정표를 이용하여 환산하 였다(16).

\section{통계처리}

실험 결과의 통계처리는 평균(mean)과 표준편차(SD)로 표시하였고 SPSS 12.0(SPSS Inc., Chicago, IL, USA) 통계 프로그램을 이용하여 일원배치 분산분석을 사용하여 $\mathrm{p}<0.05$ 수준에서 Duncan's multiple range test(DMRT)로 평 균 간 다중비교를 하였다.

\section{결과 및 고찰}

\section{합성배지와 쌀 당화액 배지의 효모 생육도}

본 연구에 사용한 저온 적응성 효모 SCY 297을 상업용 종균으로 만들기 위해서는 짧은 시간에 균수를 높이는 것이 중요하다. 미생물 배양에 널리 사용되는 합성배지(YPD)를 기준으로 쌀을 당화한 당화액, 그리고 일부 영양원을 첨가 하였을 때 효모 개체수가 증가하는 정도를 Table 1에 나타 내었다. 합성배지의 경우 $5.59 \log \mathrm{CFU} / \mathrm{mL}$, 쌀 당화액은 $5.86 \log \mathrm{CFU} / \mathrm{mL}$ 으로 쌀 당화액에서 효모 개체수가 높게 나타난 것을 알 수 있었다. 합성배지에 미생물 생육 영양원 인 효모 추출물, 펩톤, 덱스트린을 각각 $2 \%$ 첨가하였을 때, 효모의 생육은 5.89, 5.97 및 $6.04 \log \mathrm{CFU} / \mathrm{mL}$ 로 증가하 였다. 쌀 당화액에 효모 추출물, 펩톤을 첨가하여 배양한 결과, $6.14 \log \mathrm{CFU} / \mathrm{mL}$ 로 대조구인 합성배지보다 $10 \%$, 쌀 당화액보다 $2 \%$ 높게 나타났다. 쌀 당화액이 합성배지보다 효모의 생육에 필요한 다양한 영양분을 함유한 것으로 보인 다. 특히, 쌀 당화액에 질소원을 첨가하면 효모의 생육이 더욱 촉진하는 것을 알 수 있었다. 현재, 국내에서는 쌀

Table 1. Viable yeast cell counts of cold adaptive SCY297 cultured in synthetic medium (YPD) and saccharified medium

\begin{tabular}{|c|c|c|c|c|c|}
\hline \multirow[b]{2}{*}{ Con (YPD) } & \multicolumn{5}{|c|}{ Viable yeast cell counts (log CFU/mL) } \\
\hline & $\begin{array}{c}\text { YPD } \\
+ \\
\text { Yeast extract }\end{array}$ & $\begin{array}{c}\text { YPD } \\
+ \\
\text { Peptone }\end{array}$ & $\begin{array}{c}\text { YPD } \\
+ \\
\text { Dextrose }^{5}\end{array}$ & Saccharified medium & $\begin{array}{l}\text { Saccharified medium } \\
\qquad+\mathrm{YE}^{3 / 1}+\mathrm{P}^{4)}\end{array}$ \\
\hline $5.59 \pm 0.040^{1 / 22)}$ & $5.89 \pm 0.066^{b}$ & $5.97 \pm 0.080^{\mathrm{bc}}$ & $6.04 \pm 0.056^{\mathrm{c}}$ & $5.86 \pm 0.114^{\mathrm{b}}$ & $6.14 \pm 0.040^{\mathrm{d}}$ \\
\hline
\end{tabular}

\footnotetext{
${ }^{1)}$ Data are means \pm SD $(n=3)$.

${ }^{2) a-d}$ Means in a row by different superscripts are significantly different at $5 \%$ significance level by Duncan's multiple range test.

${ }^{3)-5)}$ Yeast extract (YE), peptone (P), dextrose were added at $2 \%$, respectively.
} 
당화액을 이용하여 효모를 상업적으로 배양하고 있진 않 다. 하지만 최근, 제빵에 사용되는 효모를 쌀을 이용한 발효 액제조에 사용하는 시도가 이루어지고 있다(17). 실험실 조건에서는 쌀을 이용한 발효액종이나 효모 발효액 제조가 가능하나, 산업적으로 대규모 생산하기 위해서는 원료의 경제성, 공정의 효율성 등에 대한 검토가 필요한 것으로 판단된다.

제형화 및 저장기간에 따른 효모 생존율 변화

저온 적응성이 뛰어난 효모 SCY 297의 산업용 종균제로 제조하기 위하여 동결건조, 송풍건조, 액체 형태 등 다양한 제형 조건으로 $25^{\circ} \mathrm{C}$ 에서 15 주간 저장에 따른 효모 생존율을 생균수로 측정하여 조사하였다. 또한 부형제 종류별(스킴 밀크, 알파 락토오스, 트레할로오스)로 각각 $5 \%$ 씩 첨가하여 SCY 297 효모의 생존율을 측정하였다. 동결건조 방법으로 효모를 제형화한 후, 저장 기간과 부형제 종류에 따른 생존 율 측정 결과를 Fig. 2 에 나타내었다. 부형제 무첨가 상태로 동결 건조한 경우, 4주 차 생균수는 $5.99 \log \mathrm{CFU} / \mathrm{mL}$, 상대적 생존율은 $95.6 \%$ 로 높게 나타났다. 하지만 15 주 차 생균수는 $1.43 \log \mathrm{CFU} / \mathrm{mL}$, 상대적 생존율은 $22.9 \%$ 로 저장 기간이 오래될수록 효모의 생존율이 저하되었다. 부형제인 스킴 밀크를 사용하였을 때, 15 주 차 생균수는 $5.17 \log \mathrm{CFU} / \mathrm{mL}$, 상대적 생존율은 $82.3 \%$ 로 부형제 무첨가보다 약 4 배의 높은 생존율을 나타내었다. 또한 알파 락토오스 및 트레할로오스 부형제 첨가시 상대적 생존율이 각각 $73.9 \%, 79.9 \%$ 로 나타 난 것으로 보아 부형제의 사용이 효모의 생존
율에 큰 영향을 미치는 것으로 확인하였다. 균주를 동결건 조 할 때, 세포벽 파괴 방지를 위해 부형제인 스킴밀크를 대부분 사용하며 이들의 농도는 5-10\% 내외로 첨가한 것이 미생물 생존율 향상에 도움이 된다고 보고하였다(18). 또한 Abadias 등(9)은 부형제로 당 종류 중 갈락토오스, 락토오 스, 트레할로오스 및 라피노오스의 $5-10 \%$ 농도에서 Candida sake 의 동결건조시 생존율을 높은 것으로 보고하 였다. 건조에 대한 생존율을 높이기 위해서는 균주마다 적 합한 당의 선정이 중요한 것으로 보여진다.

송풍건조 방법으로 효모를 제형화한 후, 저장 기간과 부 형제에 따른 효모 생존율 결과를 Fig. 3에 나타내었다. 부형 제 무첨가의 경우, 4 주 차 생균수는 $5.97 \log \mathrm{CFU} / \mathrm{mL}$, 상대 적 생존율은 $96.8 \%$ 로 동결건조한 생균수와 차이가 없었다. 하지만 15 주 차 생균수가 측정되지 않아 장기저장에 부적 합한 것으로 판단된다. 또한 알파 락토오스, 트레할로오스 부형제 첨가군에서도 효모가 생육되지 않아 송풍건조시 장기저장에 적합하지 않은 부형제로 판단된다. 부형제 중 스킴 밀크만이 15 주 차에 생균수가 측정되어 $5.11 \mathrm{log}$ $\mathrm{CFU} / \mathrm{mL}$, 상대적 생존율은 $82.3 \%$ 로 나타났으며, 동결건조 에 의한 생존율과 유사하였다. Lee 등(18)은 S. cerevisiae $\mathrm{D} 8$ 균주는 송풍 건조시 가장 높은 생존율에 영향 주는 부형 제로 트레할로오스(생존율 97.5\%)이며, Hanseniaspora uvarum S6은 슈크로오스(생존율 92.6\%)라고 보고하였다. 이는 효모 균주마다 가지는 특성의 차이와 제조조건에 따라 맞춤형 부형제가 필요한 것을 알 수 있다.

액체 방법으로 효모를 제형화한 후, 저장 기간과 부형제
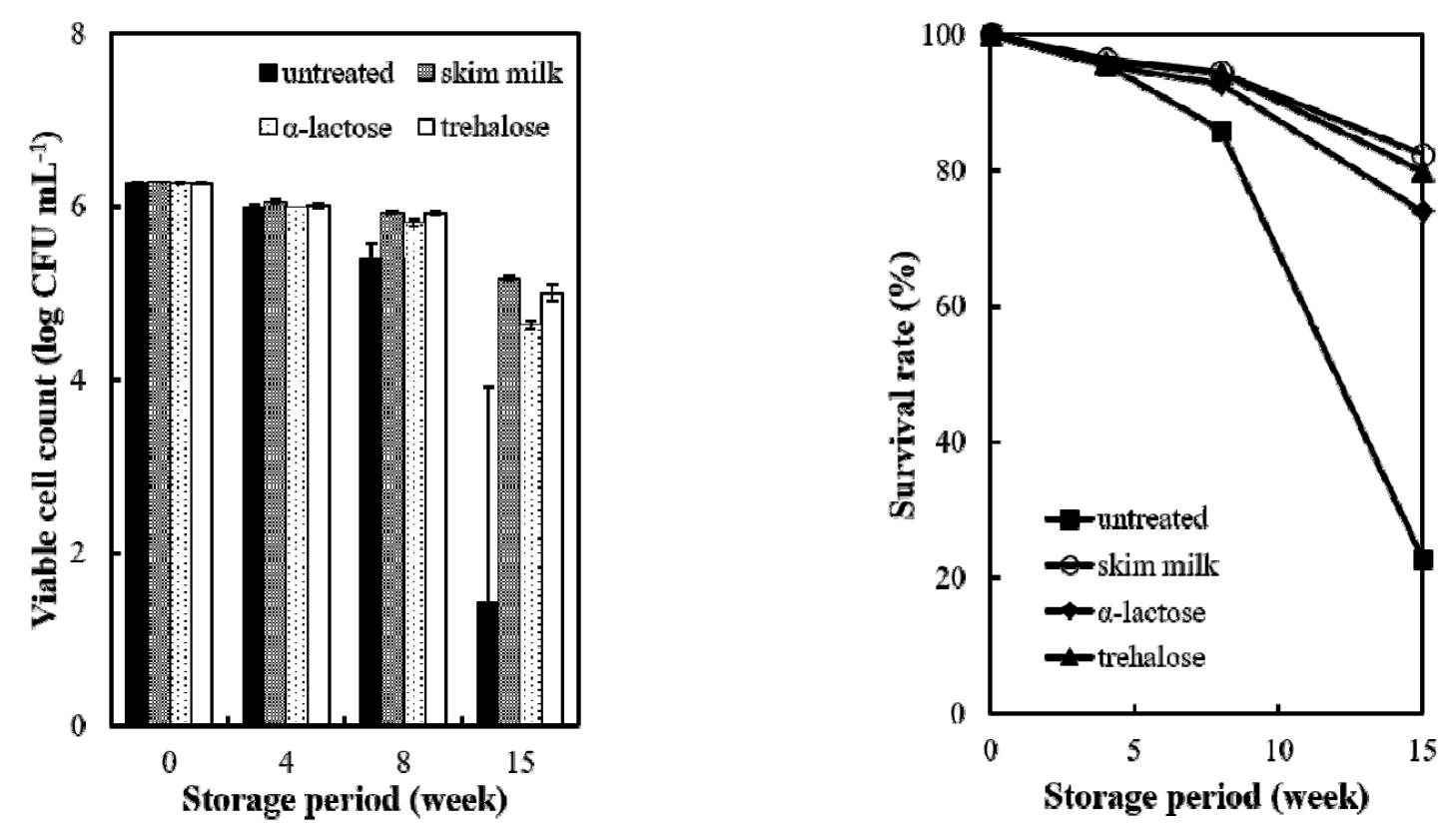

Fig. 2. Changes in the viable count (left panel) and survival rate (right panel) of freeze-dried formulation yeast cells stored at $25^{\circ} \mathrm{C}$ for 15-week. 5\% skimmed milk, a-lactose or trehalose was used as a protective agents for cold adaptive S. cerevisiae Y297, respectively. All data are expressed as the mean \pm SD $(\mathrm{n}=3)$. 

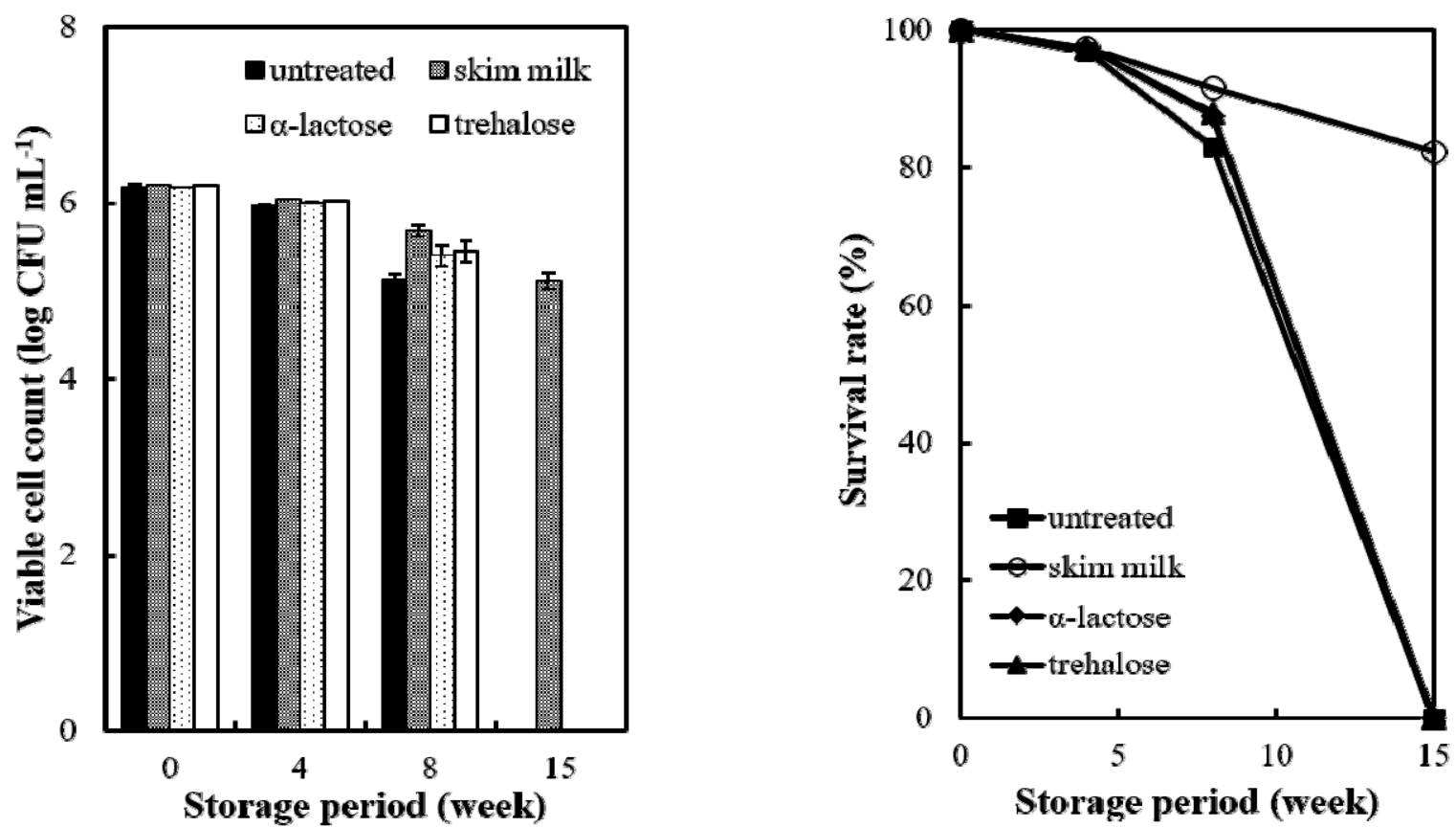

Fig. 3. Changes in the viable count (left panel) and survival rate (right panel) of air blast-dried formulation yeast cells stored at $25^{\circ} \mathrm{C}$ for 15-week. 5\% skimmed milk, a-lactose or trehalose was used as a protective agents for cold adaptive S. cerevisiae Y297, respectively. All data are expressed as the mean \pm SD $(n=3)$.
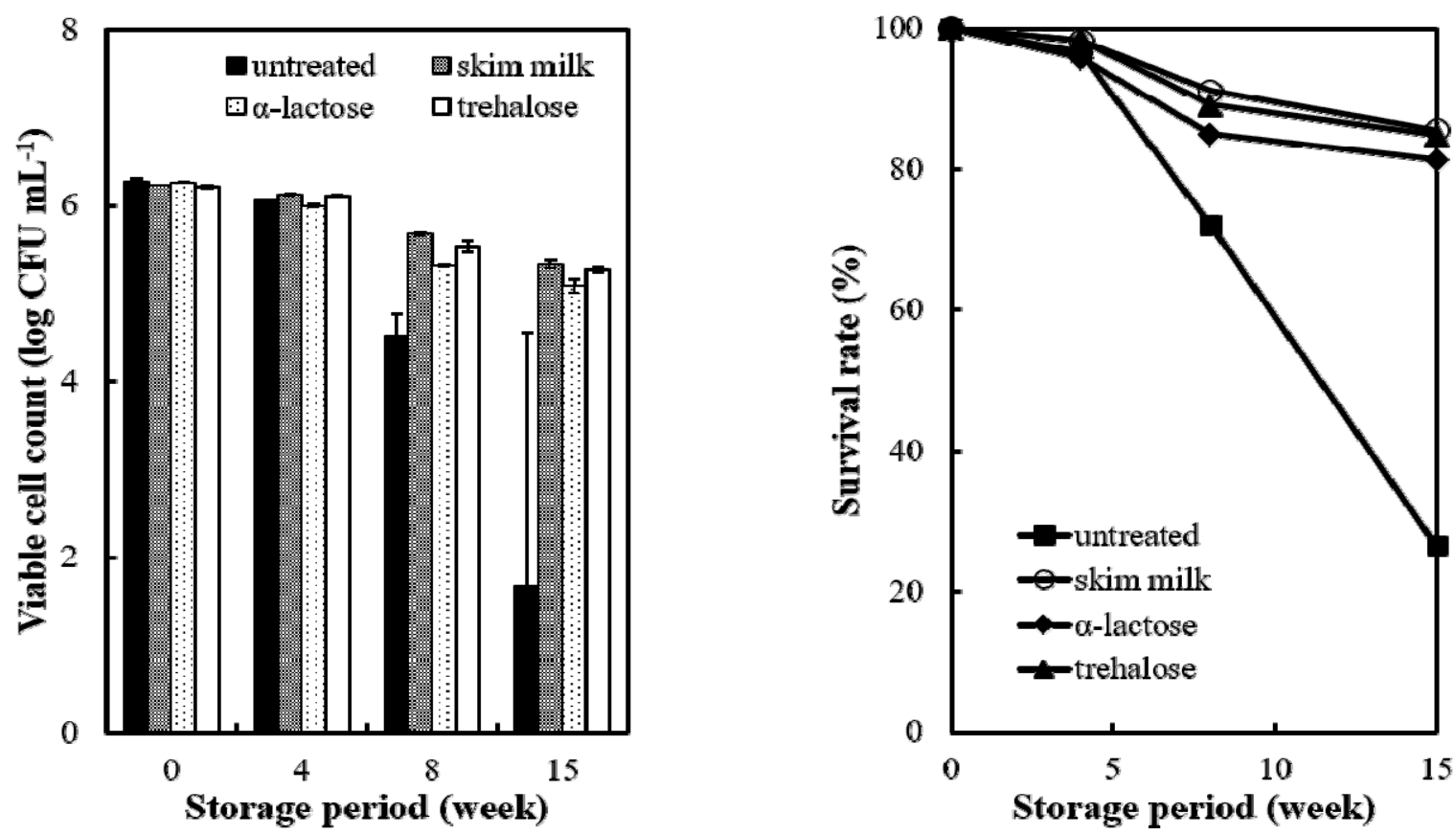

Fig. 4. Changes in the viable count (left panel) and survival rate (right panel) of liquid formulation yeast cells stored at $25^{\circ} \mathrm{C}$ for 15 -week. 5\% skimmed milk, a-lactose or trehalose was used as a protective agents for low temperature-adaptive S. cerevisiae Y297, respectively. All data are expressed as the mean \pm SD $(n=3)$.

에 따른 생존율 결과를 Fig. 4 에 나타내었다. 대조구로써 부형제 무첨가 액체 종균의 경우, 4 주 차 생균수는 $6.06 \log$ $\mathrm{CFU} / \mathrm{mL}$, 상대적 생존율은 $96.6 \%$ 로 동결건조법 및 송풍건
조법에 의한 생균수와 차이가 없었다. 15 주 차 생균수는 1.67 $\log \mathrm{CFU} / \mathrm{mL}$, 상대적 생존율은 $26.6 \%$ 로 부형제 첨가 없이 효모의 장기저장은 어려운 것으로 나타났다. 하지만 부형제 
를 첨가한 액체 제형의 경우, 사용한 3종류 부형제 모두 효모 의 생존율에 긍정적인 영향을 주는 것으로 나타났다. 15 주 차 스킴 밀크의 상대적 생존율은 $85.5 \%$, 알파 락토오스의 상대적 생존율은 $81.3 \%$, 트레할로오스의 상대적 생존율은 $84.8 \%$ 로 나타나 동결건조 및 송풍건조 방법보다 저온 적응성 효모 SCY297의 제형은 액체 제형이 장기저장에 유용한 것으 로 판단된다.
효모 제형 형태와 저장기간에 따른 약주의 양조적성 평가 저온 적응성 효모 SCY 297의 제형화 및 저장 기간별로 약주를 제조하여 이들의 양조적성을 평가하였다. 제형화 전의 효모 SCY 297 , 저장기간 4주, 10 주, 15 주 차의 동결건 조 방법으로 제형화된 효모로 각각의 약주를 제조하여 품질 분석을 한 결과를 Table 2에 나타내었다. 제형화 전의 효모 와 동결건조 되어 저장기간에 따라 차이나는 것은 $\mathrm{pH}$, 적정

Table 2. Physicochemical properties of Yakju made from cold adaptive yeast of freeze-dried formulation cells using SCY297 and not freeze-dried formulation cells using SCY297

\begin{tabular}{|c|c|c|c|c|c|c|}
\hline $\begin{array}{l}\text { Storage period } \\
\text { (week) }\end{array}$ & Protective agent $(5 \%)$ & $\mathrm{pH}$ & $\begin{array}{l}\text { Soluble solid } \\
\left({ }^{\circ} \text { Brix }\right)\end{array}$ & $\begin{array}{c}\text { Titratable acidity } \\
(\%, \mathrm{v} / \mathrm{v})\end{array}$ & $\begin{array}{l}\text { Amino acidity } \\
(\mathrm{mL})\end{array}$ & $\begin{array}{l}\text { Alcohol } \\
(\%, \mathrm{v} / \mathrm{v})\end{array}$ \\
\hline \multicolumn{2}{|c|}{ Control (SCY297) } & $3.49 \pm 0.01^{1) \mathrm{de} 2)}$ & $12.30 \pm 0.10^{c}$ & $0.53 \pm 0.01^{\mathrm{g}}$ & $3.03 \pm 0.06^{\mathrm{e}}$ & $19.30 \pm 0.10^{\mathrm{a}}$ \\
\hline \multirow{4}{*}{4} & Untreated & $3.04 \pm 0.00^{f}$ & $12.20 \pm 0.10^{\mathrm{cd}}$ & $0.45 \pm 0.01^{\mathrm{h}}$ & $3.48 \pm 0.16^{\mathrm{e}}$ & $15.03 \pm 0.15^{\mathrm{e}}$ \\
\hline & Skim milk & $3.00 \pm 0.01^{\mathrm{f}}$ & $11.00 \pm 0.00^{g}$ & $0.45 \pm 0.02^{\mathrm{h}}$ & $3.06 \pm 0.00^{e}$ & $15.03 \pm 0.06^{\mathrm{e}}$ \\
\hline & a-Lactose & $3.30 \pm 0.00^{\mathrm{e}}$ & $12.20 \pm 0.20^{\mathrm{cd}}$ & $0.46 \pm 0.00^{\mathrm{h}}$ & $2.22 \pm 0.01^{\mathrm{e}}$ & $14.17 \pm 0.06^{\mathrm{g}}$ \\
\hline & Trehalose & $3.02 \pm 0.02^{\mathrm{f}}$ & $11.47 \pm 0.11^{\mathrm{f}}$ & $0.47 \pm 0.03^{\mathrm{h}}$ & $3.00 \pm 0.01^{\mathrm{e}}$ & $14.07 \pm 0.06^{\mathrm{g}}$ \\
\hline \multirow{4}{*}{10} & Untreated & $3.67 \pm 0.04^{d}$ & $13.67 \pm 0.12^{\mathrm{a}}$ & $0.91 \pm 0.05^{\mathrm{d}}$ & $10.67 \pm 0.55^{\text {cd }}$ & $15.57 \pm 0.06^{b}$ \\
\hline & Skim milk & $4.53 \pm 0.34^{\mathrm{a}}$ & $12.07 \pm 0.12^{\mathrm{d}}$ & $0.80 \pm 0.07^{\mathrm{e}}$ & $10.00 \pm 0.21^{\mathrm{d}}$ & $15.37 \pm 0.15^{\text {cd }}$ \\
\hline & a-Lactose & $3.65 \pm 0.04^{\mathrm{d}}$ & $11.87 \pm 0.12^{\mathrm{e}}$ & $0.78 \pm 0.06^{\mathrm{e}}$ & $11.66 \pm 0.96^{\mathrm{c}}$ & $15.03 \pm 0.06^{\mathrm{e}}$ \\
\hline & Trehalose & $4.26 \pm 0.27^{\mathrm{b}}$ & $12.53 \pm 0.06^{b}$ & $0.72 \pm 0.04^{f}$ & $10.96 \pm 0.51^{\text {cd }}$ & $14.83 \pm 0.06^{\mathrm{f}}$ \\
\hline \multirow{4}{*}{15} & Untreated & $4.19 \pm 0.02^{\mathrm{bc}}$ & $12.53 \pm 0.06^{b}$ & $1.04 \pm 0.03^{\mathrm{bc}}$ & $15.25 \pm 1.06^{b}$ & $15.43 \pm 0.06^{\mathrm{bc}}$ \\
\hline & Skim milk & $4.07 \pm 0.04^{\mathrm{bc}}$ & $12.37 \pm 0.06^{\mathrm{bc}}$ & $1.14 \pm 0.05^{\mathrm{a}}$ & $17.26 \pm 2.49^{\mathrm{c}}$ & $15.23 \pm 0.36^{\mathrm{d}}$ \\
\hline & a-Lactose & $4.02 \pm 0.01^{\mathrm{c}}$ & $11.57 \pm 0.06^{\mathrm{f}}$ & $1.09 \pm 0.03^{\mathrm{ab}}$ & $14.83 \pm 0.81^{\mathrm{b}}$ & $14.83 \pm 0.06^{\mathrm{f}}$ \\
\hline & Trehalose & $4.14 \pm 0.04^{\mathrm{bc}}$ & $12.07 \pm 0.06^{\mathrm{d}}$ & $1.02 \pm 0.02^{\mathrm{c}}$ & $14.29 \pm 0.22^{\mathrm{b}}$ & $15.03 \pm 0.03^{\mathrm{e}}$ \\
\hline
\end{tabular}

${ }^{1)}$ Data are means \pm SD $(n=3)$.

2)a-h Means in a row by different superscripts are significantly different at $5 \%$ significance level by Duncan's multiple range test.

Table 3. Physicochemical properties of Yakju made from cold adaptive yeast of air blast-dried formulation cells using SCY297 and not air blast-dried formulation cells using SCY297

\begin{tabular}{|c|c|c|c|c|c|c|}
\hline $\begin{array}{l}\text { Storage period } \\
\text { (week) }\end{array}$ & Protective agent (5\%) & $\mathrm{pH}$ & $\begin{array}{l}\text { Soluble solid } \\
\left({ }^{\circ} \text { Brix }\right)\end{array}$ & $\begin{array}{l}\text { Titratable acidity } \\
(\%, \mathrm{v} / \mathrm{v})\end{array}$ & $\begin{array}{l}\text { Amino acidity } \\
(\mathrm{mL})\end{array}$ & $\begin{array}{l}\text { Alcohol } \\
(\%, \mathrm{v} / \mathrm{v})\end{array}$ \\
\hline \multicolumn{2}{|c|}{ Control (SCY297) } & $3.49 \pm 0.01^{1) \mathrm{d} 2}$ & $12.30 \pm 0.10^{\mathrm{d}}$ & $0.53 \pm 0.01^{\mathrm{b}}$ & $3.03 \pm 0.06^{\mathrm{a}}$ & $19.30 \pm 0.10^{\mathrm{a}}$ \\
\hline \multirow{4}{*}{4} & Untreated & $3.73 \pm 0.10^{c}$ & $11.80 \pm 0.20^{c}$ & $0.68 \pm 0.06^{b}$ & $7.97 \pm 0.67^{\mathrm{b}}$ & $16.03 \pm 0.15^{\mathrm{d}}$ \\
\hline & Skim milk & $3.98 \pm 0.12^{\mathrm{d}}$ & $11.60 \pm 0.00^{b}$ & $0.64 \pm 0.05^{\mathrm{b}}$ & $7.81 \pm 0.76^{b}$ & $15.63 \pm 0.06^{\mathrm{e}}$ \\
\hline & a-Lactose & $3.28 \pm 0.16^{\mathrm{a}}$ & $11.33 \pm 0.12^{\mathrm{a}}$ & $0.69 \pm 0.07^{\mathrm{b}}$ & $11.65 \pm 0.70^{\mathrm{cd}}$ & $14.83 \pm 0.06^{\mathrm{g}}$ \\
\hline & Trehalose & $3.18 \pm 0.06^{\mathrm{a}}$ & $11.67 \pm 0.12^{\mathrm{bc}}$ & $0.68 \pm 0.06^{b}$ & $10.79 \pm 0.30^{\mathrm{c}}$ & $16.77 \pm 0.10^{\mathrm{c}}$ \\
\hline \multirow{4}{*}{10} & Untreated & $4.16 \pm 0.01^{\mathrm{e}}$ & $12.90 \pm 0.00^{\mathrm{f}}$ & $1.02 \pm 0.04^{\mathrm{c}}$ & $12.95 \pm 2.16^{\mathrm{de}}$ & $16.80 \pm 0.00^{\mathrm{c}}$ \\
\hline & Skim milk & $4.16 \pm 0.04^{\mathrm{e}}$ & $12.17 \pm 0.06^{\mathrm{d}}$ & $1.06 \pm 0.03^{\mathrm{c}}$ & $14.04 \pm 0.84^{\mathrm{e}}$ & $16.03 \pm 0.06^{d}$ \\
\hline & a-Lactose & $3.92 \pm 0.03^{\mathrm{d}}$ & $12.43 \pm 0.06^{\mathrm{e}}$ & $1.34 \pm 0.01^{\mathrm{e}}$ & $16.70 \pm 0.80^{\mathrm{f}}$ & $15.37 \pm 0.06^{\mathrm{f}}$ \\
\hline & Trehalose & $3.95 \pm 0.07^{\mathrm{d}}$ & $12.20 \pm 0.00^{\mathrm{d}}$ & $1.22 \pm 0.02^{\mathrm{d}}$ & $16.12 \pm 0.76^{\mathrm{f}}$ & $17.17 \pm 0.10^{b}$ \\
\hline \multirow{4}{*}{15} & Untreated & - & - & - & - & - \\
\hline & Skim milk & - & - & - & - & - \\
\hline & a-Lactose & - & - & - & - & - \\
\hline & Trehalose & - & - & - & - & - \\
\hline
\end{tabular}

${ }^{1)}$ Data are means \pm SD $(n=3)$.

${ }^{2) a-f}$ Means in a row by different superscripts are significantly different at $5 \%$ significance level by Duncan's multiple range test. 
산도, 아미노산도, 알코올 함량으로 나타났다. 대조구로써 비제형화된 효모의 $\mathrm{pH}$, 적정산도, 아미노산도, 알코올 함량 은 각각 $3.49,0.53,3.03,19.9 \%$ 인데 반해, 제형화시킨 4 주 차 동결건조 효모로 빚은 약주는 각각 3.0-3.3, 0.45-0.47, $2.22-3.48,14.07-15.03 \%$ 이며, 15 주 차는 각각 4.02-4.19, $1.02-1.14,14.29-17.26,14.83-15.43 \%$ 로 나타났다. 고형분 함량을 살펴보면 제형화 전 약주와 제형화후 저장기간에 따라 제조된 약주의 고형분 함량 차이가 작은 것으로 나타 났다. 제형화 전의 효모에 비해 동결건조 후, 저장기간이 오래될수록 알코올 발효 특성에 영향을 미치는 것으로 보인 다. 특히, 아미노산도의 급격한 증가와 알코올 함량 감소 부분이 효모의 동결건조와 부형제에 의한 영향인지는 추가 적인 연구가 필요하다.

비제형화 SCY 297 , 저장기간 4주, 10 주 차의 송풍건조 방법으로 제형화된 효모로 약주를 제조한 결과는 Table 3 과 같다. 4 주 차 송풍건조 효모의 약주 $\mathrm{pH}$, 적정산도, 아미노산 도, 알코올 함량은 각각 3.18-3.98, 0.64-0.69, 7.81-11.65, $14.83-16.77 \%$ 이며, 10 주 차는 3.95-4.16, 1.02-1.34, 14.04$16.70,15.37-17.17 \%$ 로 나타났다. 송풍건조로 제형화된 효 모는 비제형화 효모로 제조된 약주의 고형분 함량에 비해 차이가 작게 나타나 동결건조된 효모와 유사하게 특성을 보였다.

제형화 전의 효모 SCY 297, 저장기간 4주, 15 주 차의 액체 방법으로 제형화된 효모로 약주를 제조하여 품질을 분석한 결과는 Table 4에 나타내었다. 4주 차 액체 형태 효모의 약주 $\mathrm{pH}$, 적정산도, 아미노산도, 알코올 함량은 각각 3.44-3.47, $0.53-0.56,3.10-3.42,18.5-19.6 \%$ 이며, 15 주 차는 4.44-5.35,
0.56-0.65, 6.07-8.13, 17.0-18.2\%로 나타났다. 액체 효모의 경우, 제형화 전에 비해 알코올 함량의 변화는 동결건조 및 송풍건조 방법에 비해 낮게 나타났으나, $\mathrm{pH}$ 와 고형분 함량이 증가한 것으로 나타났다. 동결건조, 송풍건조 및 액체 제형화 효모의 저장기간에 따라 약주를 발효하였을 때, 이들의 품질변화를 살펴본 결과, 액체 효모가 비제형화 효모에 비해 품질변화가 가장 적은 것으로 나타났다. 특히, 알코올 생산성은 동결건조 효모가 $15 \%$ 내외, 송풍건조 효 모는 $17 \%$ 내외, 액체 효모는 $19 \%$ 정도로 비제형화 효모와 유사하였다. 이는 동결건조 및 송풍건조에 비해 액체 저장 법이 효모에 스트레스 자극이 적은 것으로 판단되며, 효모 고유의 특성을 유지하는 것으로 본 실험에서 확인하였다.

효모 제형화 방법인 동결건조, 송풍건조 및 액체 형태와 효모 부형제에 따른 종균 제형의 저장기간과 생존율 및 발효 특성 등을 분석하였다. 동결건조, 액체의 경우, 부형제 를 첨가하면 실온에서 15 주까지 약 $80 \%$ 이상의 생존율을 나타냈었고 송풍건조는 skim milk만이 약 $80 \%$ 이상의 생존 율을 보였다. 제형화된 효모의 발효 특성은 약주를 발효하 여 그 술덧을 분석한 결과, 동결건조 및 송풍건조 효모는 대조구에 비해 적정산도, 아미노산도가 증가하였고, 알코 올 함량은 감소하였다. 반면 액체 효모는 제형화 전에 비해 $\mathrm{pH}$, 고형분 함량, 아미노산도가 증가 폭이 낮았고, 알코올 함량의 감소 또한 낮게 나타났다. 이런 결과를 종합해보면, 저온 적응성 효모 SCY297의 제형화는 액상형 종균화가 하나의 대안이 될 수 있는 가능성을 제시하였다.

Table 4. Physicochemical properties of Yakju made from cold adaptive yeast of liquid formulation cells using SCY297 and not liquid formulation cells using SCY297

\begin{tabular}{|c|c|c|c|c|c|c|}
\hline $\begin{array}{l}\text { Storage period } \\
\text { (week) }\end{array}$ & Protective agent $(5 \%)$ & $\mathrm{pH}$ & $\begin{array}{l}\text { Soluble solid } \\
\left({ }^{\circ} \text { Brix }\right)\end{array}$ & $\begin{array}{l}\text { Titratable acidity } \\
(\%, \mathrm{v} / \mathrm{v})\end{array}$ & $\begin{array}{l}\text { Amino acidity } \\
(\mathrm{mL})\end{array}$ & $\begin{array}{l}\text { Alcohol } \\
(\%, \mathrm{v} / \mathrm{v})\end{array}$ \\
\hline \multicolumn{2}{|c|}{ Control (SCY297) } & $3.49 \pm 0.01^{1 / 22)}$ & $12.30 \pm 0.10^{e}$ & $0.53 \pm 0.01^{\mathrm{d}}$ & $3.03 \pm 0.06^{\mathrm{f}}$ & $19.30 \pm 0.10^{b}$ \\
\hline \multirow{4}{*}{4} & Untreated & $3.44 \pm 0.00^{c}$ & $14.43 \pm 0.01^{\mathrm{d}}$ & $0.55 \pm 0.14^{\text {cd }}$ & $3.01 \pm 0.01^{\mathrm{f}}$ & $19.63 \pm 0.06^{\mathrm{a}}$ \\
\hline & Skim milk & $3.45 \pm 0.01^{\mathrm{c}}$ & $14.30 \pm 0.10^{\mathrm{d}}$ & $0.53 \pm 0.01^{\mathrm{d}}$ & $3.16 \pm 0.01^{\mathrm{f}}$ & $19.27 \pm 0.06^{b}$ \\
\hline & a-Lactose & $3.47 \pm 0.01^{\mathrm{c}}$ & $14.30 \pm 0.10^{d}$ & $0.56 \pm 0.01^{\mathrm{bcd}}$ & $3.42 \pm 0.02^{\mathrm{f}}$ & $19.37 \pm 0.06^{b}$ \\
\hline & Trehalose & $3.45 \pm 0.01^{\mathrm{c}}$ & $14.47 \pm 0.12^{\mathrm{d}}$ & $0.57 \pm 0.02^{\mathrm{bcd}}$ & $3.20 \pm 0.01^{\mathrm{f}}$ & $18.53 \pm 0.06^{\mathrm{c}}$ \\
\hline \multirow{4}{*}{10} & Untreated & $4.38 \pm 0.04^{b}$ & $15.67 \pm 0.12^{\mathrm{bc}}$ & $0.61 \pm 0.07^{\mathrm{ab}}$ & $5.39 \pm 0.54^{\mathrm{e}}$ & $18.36 \pm 0.15^{\mathrm{d}}$ \\
\hline & Skim milk & $4.46 \pm 0.01^{\mathrm{b}}$ & $15.93 \pm 0.12^{\mathrm{ab}}$ & $0.60 \pm 0.05^{\mathrm{abc}}$ & $6.52 \pm 0.49^{\mathrm{cd}}$ & $17.43 \pm 0.15^{\mathrm{g}}$ \\
\hline & a-Lactose & $4.75 \pm 0.56^{b}$ & $15.90 \pm 0.10^{\mathrm{abc}}$ & $0.61 \pm 0.04^{\mathrm{ab}}$ & $6.79 \pm 0.63^{\text {bcd }}$ & $18.56 \pm 0.06^{\mathrm{C}}$ \\
\hline & Trehalose & $4.82 \pm 0.52^{\mathrm{b}}$ & $15.73 \pm 0.15^{\mathrm{abc}}$ & $0.53 \pm 0.04^{d}$ & $6.91 \pm 0.52^{b c}$ & $18.03 \pm 0.15^{\mathrm{e}}$ \\
\hline \multirow{4}{*}{15} & Untreated & $4.86 \pm 0.35^{\mathrm{ab}}$ & $15.73 \pm 0.31^{\text {abc }}$ & $0.65 \pm 0.02^{\mathrm{a}}$ & $6.07 \pm 0.23^{\text {de }}$ & $17.78 \pm 0.06^{\mathrm{f}}$ \\
\hline & Skim milk & $4.44 \pm 0.20^{b}$ & $15.67 \pm 0.23^{\mathrm{bc}}$ & $0.58 \pm 0.01^{\mathrm{bcd}}$ & $7.05 \pm 0.78^{\mathrm{bc}}$ & $16.97 \pm 0.06^{\mathrm{h}}$ \\
\hline & a-Lactose & $5.35 \pm 0.61^{\mathrm{a}}$ & $15.60 \pm 0.20^{\mathrm{c}}$ & $0.60 \pm 0.02^{\mathrm{abc}}$ & $7.60 \pm 0.56^{\mathrm{ab}}$ & $18.23 \pm 0.03^{\mathrm{d}}$ \\
\hline & Trehalose & $4.68 \pm 0.03^{\mathrm{b}}$ & $16.00 \pm 0.20^{\mathrm{a}}$ & $0.56 \pm 0.01^{\text {bcd }}$ & $8.13 \pm 0.63^{\mathrm{a}}$ & $17.43 \pm 0.06^{\mathrm{g}}$ \\
\hline
\end{tabular}

${ }^{1)}$ Data are means \pm SD $(n=3)$.

${ }^{2) a-h}$ Means in a row by different superscripts are significantly different at $5 \%$ significance level by Duncan's multiple range test. 


\section{요 약}

저온 적응성 효모 SCY297의 종균 방법에 따른 생존율과 약주 제조시 양조 특성을 조사하였다. 동결건조, 송풍건조 및 액체 제형 방법으로 제조한 다음, 실온에서 장기 저장에 따른 효모의 생존율과 양조 특성을 비교하였다. 또한, 부형 제로 skim milk, a-lactose, trehalose를 5\%씩 첨가하여 생존 율과 양조특성에 미치는 영향을 조사하였다. 부형제가 첨 가된 동결건조 및 액체 제형 SCY297 효모는 실온에서 15 주 까지 약 $80 \%$ 이상의 생존율을 나타내었고, 송풍건조는 skim milk 첨가한 경우만 약 $80 \%$ 이상 생존율을 나타내었 다. 저장기간 및 제형화된 효모 SCY297로 약주를 발효하여 그 술덧을 분석한 결과, 동결건조 및 송풍건조된 SCY297는 무처리 SCY297보다 적정산도는 0.61 , 아미노산도는 14.23 증가하였고, 알코올 함량은 $5.07 \%$ 감소하였다. 액체 SCY297는 무처리 SCY297보다 $\mathrm{pH} 1.86$, 아미노산도는 5.1 증가하였고, 알코올 함량은 $2.9 \%$ 로 감소량이 낮았다. 따라 서 본 연구 결과, 종래의 고상형 방법보다 액상형 방법을 통한 종균화 가능성을 제시하였다.

\section{감사의 글}

This work was carried out with the support of "Cooperative Research Program for Agriculture Science \& Technology Development (Project No. PJ01198401)" Rural Development Administration, Republic of Korea.

\section{References}

1. Lee DH, Kang HY, Lee YS, Cho CH, Kim SJ, Lee JS (2011) Quality of Korean Yakju. Korean J Microbiol Biotechnol, 39, 274-280

2. Kim HR, Kim JH, Bai DH, Ahn BH (2012) Feasibility of Brewing Makgeolli using Pichia anomala Y197-13, a Non-Saccharomyces cerevisiae. J Microbiol Biotechnol, 22, 1749-1757

3. Baek SY, Lee YJ, Kim MD, Yi JH, Mun JY, Yeo SH (2015) Characterization of ethanol fermentation with wild type yeast strains. Microbiol Biotechnol, 43, 227-235

4. Hong YA, Park HD (2013) Role of non-Saccharomyces yeasts in Korean wines produced from Campbell Early grapes: potential use of Hanseniaspora uvarum as a starter culture. Food Microbiol, 34, 207-214

5. Baek SY, Lee YJ, Kim JH, Yeo SH (2015) Isolation and characterization of wild yeasts for improving liquor flavor and quality. Microbiol Biotechnol, 43, 56-64

6. Ale CE, Otero MC, Pasteris SE (2015) Freeze-drying of wine yeasts and Oenococcus oeni and selection of the inoculation conditions after storage. J Bioprocess Biotech, 5, 248-253

7. Bayrock D, Ingledew WM (1997) Mechanism of viability loss during fluidized bed drying of baker's yeast. Food Res Int, 30, 417-425

8. Luna-Solano G, Salgado-Cervantes MA, RodriguezJimenes GC, Garcia-Alvarado MA (2005) Optimization of brewer's yeast spray drying process. J Food Eng, 68, 9-18

9. Abadias M, Benabarre A, Teixido N, Usaii J, Vinas I (2001) Effect of freeze drying and protectants on viability of the biocontrol yeast Candida sake. Int $\mathrm{J}$ Food Microbiol, 65, 173-182

10. George JP, Datta AK (2002) Development and validation of heat and mass transfer models for freeze-drying of vegetable slices. J Food Eng, 25, 89-93

11. Santivarangkna C, Kulozik U, Foerst P (2007) Alternative drying processes for the industrial preservation of lactic acid starter cultures. Biotechnol Prog, 23, $302-315$

12. Melin P, Hakansson S, Schnurer J (2007) Optimization and comparison of liquid and dry formulations of the biocontrol yeast Pichia anomala J121. Appl Microbiol Biotechnol, 73, 1008-1016

13. Seo DJ, Yeo SH, Mun JY, Baek SY (2016) Effects of low temperature-adapted Saccharomyces cerevisiae Y297 strain and fermentation temperature on the quality characteristics of Yakju. Korean J Food Preserv, 23, 666-672

14. Chandralekha A, Hrishikesh Tavanandi A, Amrutha N, umesh Hebbar H, Raghavarao KSMS, Ramachandra G (2016) Encapsulation of yeast (Saccharomyces cereviciae) by spray drying for extension of shelf life. Drying Technology, 34, 1307-1318

15. Im SY, Baek CH, Baek SY, Park HY, Choi HS, Choi JH, Jeong ST, Shin WC, Park HD, Yeo SH (2014) Quality characteristics of Takju according to different rice varieties and mixing ratio of Nuruk. Korean J Food Preserv, 21, 892-902

16. Kim JY, Yi YH (2010) pH, acidity, color, amino acids, reducing sugars, total sugars and alcohol in puffed millet powder containing millet Takju during fermentation. Korean J Food Sci Technol, 42, 727-732

17. Choi SH, Lee SJ (2014) Quality characteristics of Korean wheat bread prepared with substitutions of naturally 
fermented rice starters. Korean J Culinary research, 20, 100-119

18. Lee SB, Choi WS, Jo HJ, Yeo SH, Park HD (2016)
Optimization of air blast drying process for manufacturing Saccharomyces cerevisiae and non Saccharomyces yeast as industrial wine starters. AMB Expr, 6, 105-115 